\title{
Periappendicular Inflammatory Masses
}

\section{Periappendiküler Enflamatuvar Kitleler}

\author{
(1) Dursun Özgür Karakaş, (1) Metin Yeşiltaş, (1) Berk Gökçek, (1) Seracettin Eğin, () Semih Hot
}

Prof. Dr. Cemil Taşçıŏlu State Hospital, Clinic of General Surgery, İstanbul, Turkey

\section{HIIIIII| ABSTRACT}

Aim: Periappendicular inflammatory mass (PIM) defined as a mass located at the right lower quadrant of the abdomen due to inflammation, and can not clearly distinguish from borders of appendix. The aim of this study is evaluating the PIM.

Method: The patients who hospitalized for PIM evaluated retrospectively. Patient's age, gender, length of hospital stay (LOS), performing colonoscopy, comorbidity, etiology, and treatment evaluated. Also, etiology elaborated with age, gender, LOS, treatment, levels of C-reactive protein (CRP), white blood cells, neutrophil \% (Neu\%), and performing colonoscopy.

Results: One hundred fourty four patients were included to study. The mean age was $41.35 \pm 17.9$ years, and $54.2 \%$ of the patients were male. The mean LOS was $4.2 \pm 2.6$ days. Colonoscopy performed only $28.5 \%$ of the patients. The most common etiology was plastron appendicitis (PA) (75\%), and $32.4 \%$ of the PA was with abscess. $67.3 \%$ of the patients were treated conservatively (medical treatment or percutaneous drainage), and the rest treated surgically. The most common surgical approach was diagnostic laparoscopy and drainage. Malignancy reported at two right at age, LOS, treatment, CRP, Neu\%, and colonoscopy between etiologies were statistically hemicolectomy patients. The most common comorbidities were hypertension and diabetes (12.5\%, and 8.3\%, respectively). $44.4 \%$ of PIM had negative ultrasonography, $71.5 \%$ had positive CT imaging. The differences significant $(\mathrm{p}<0.05)$.

Conclusion: Not only plastron appendicitis but also Crohn's disease, diverticulitis, mucocele, and malignancy should keep in mind when evaluating the inflammatory mass of the right lower quadrant. Age, LOS, treatment, inflammatory markers, and performing colonoscopy significantly vary due to etiology.

Keywords: Periappendicular, mass, plastron appendicitis, inflammatory, right lower quadrant

\section{|IIIIIII| ÖZ}

Amaç: Periapendiküler enflamatuvar kitle (PEK), batın sağ alt kadranda lokalize, enflamasyon sonucu oluşan, apendiks ile sınırları net ayırt edilemeyen kitle olarak tanımlanmaktadır. Çalışmamızın amacı PEK değerlendirilmesidir.

Yöntem: PEK nedeni yatırılan hastalar geriye dönük değerlendirildi. Hastaların yaş, cinsiyet, hastane kalış süresi (HKS), kolonoskopi durumu, yandaş hastalıkları, etyoloji ve tedavileri değerlendirildi. Ayrıca etiyoloji; yaş, cinsiyet, HKS, tedavi, C-reaktif protein (CRP), beyaz küre (BK), nötrofil yüzdesi (Nöt\%) ve kolonoskopi durumu değerlendirildi.

Bulgular: Yüz kırk dört hasta çalışmaya dahil edildi. Yaş ortalaması 41,35 $\pm 17,9$ yıl olup, hastaların \%54,2'si ise erkekti. HKS ortalaması 4,2 $\pm 2,6$ gündü. Kolonoskopi hastaların sadece \%28,5'inde yapıldı. Plastron apandisit (PA) \%75 ile en sık etiyoloji iken, PA'ların \%32,4'simde apse gözlendi. Hastaların \%67,3'ü konservatif (medikal veya perkütan drenaj), geri kalanı ise cerrahi olarak tedavi edildi. Tanısal laparoskopi ve drenaj yapılan en sık cerrahi girişimdi. İki hemikolektomi hastasında malignite saptandı. Hipertansiyon ve diyabet (sırasıyla \%12,5 ve \%8,3) en sık saptanan yandaş hastalıklardı. Etiyolojiler arasında yaş, HKS, tedavi, CRP, Nöt\% ve kolonoskopi açısından istatistiksel olarak anlamlı fark saptandı (p<0,05).

Sonuç: Batın sağ alt kadrandaki enflamatuvar kitlelerin değerlendirilmesinde sadece plastrone apandisit değil Crohn hastalığı, divertikülit, mukosel ve maligniteler de akılda bulundurulmalıdır. Etiyolojiye bağlı olarak yaş, HKS, tedavi, enflamatuvar değerler ve kolonoskopi sonuçlarında anlamlı farklılıklar gözlenmektedir.

Anahtar Kelimeler: Periapendiküler, kitle, plastrone apandisit, enflamatuvar, sağ alt kadran

Address for Correspondence/Yazışma Adresi: Dursun Özgür Karakaş MD,

Received/Gelis Tarihi: 05.05.2020 Accepted/Kabul Tarihi: 14.05.2020

${ }^{\circ}$ Copyright 2020 by Turkish Society of Colon and Rectal Surgery

Turkish Journal of Colorectal Disease published by Galenos Publishing House. 


\section{Introduction}

Periappendicular mass is the palpable mass located at the right lower quadrant of the abdomen (RLQA), can not be clearly distinguished from borders of appendix vermiformis, and known in terminology as plastron appendicitis (PA). PA is not correctly or accurately defined this condition because of the other inflammatory disease which presenting with mass. We defined periappendicular inflammatory mass (PIM) term for an inflammatory mass located at the RLQA, which can not clearly diagnosed at ultrasonography (USG) or computed abdominal tomography (CT). PA with or without abscess, inflammatory bowel disease (IBD) (complicated Crohn disease, terminal ileitis), diverticulitis, or malignancy (microperforation) of the cecum and appendix, mucocele, abscess of neighbor tissues (tuba-ovarian or psoas abscess) constitutes PIM.

The most common complaints of PIM are abdominal pain, which began more than three days before, fever, palpable mass in the RLQA. Inflammatory biomarkers increased according to the severity and type of etiology. Initially, USG than CT should perform for further imaging. Magnetic resonance (MR) enterography or elective colonoscopy should be done to clarify or exclude the diagnosing. . $^{1,2,3,4,5,6,7}$

Treatment of PIM is varied from conservative treatment to the right hemicolectomy according to the etiology and severity. Percutaneous or surgical drainage can perform for the treatment of abscess. Interval AP recommended for $>40$ years old patients for the risk of malignancy at PA. $1,2,3,4,5,6,7$

This study aimed to evaluate the management of the periappendicular inflammatory masses in our institute.

\section{Material and Methods}

After receiving institutional approval from the ethics committee of Prof. Dr. Cemil Taşçığlu State Hospital (06.08.2019/1391), patient's records between January 2015 and October 2019 who hospitalized for PIM evaluated retrospectively. The patients peroperatively detected as complicated appendicitis excluded from the study.

The patients record evaluated for age, gender, length of hospital stay (LOS), colonoscopy, etiology, treatment, pathology, co-morbidity, and morbidity. Etiologies elaborated for age, gender, LOS, treatment, laboratory test [C-reactive protein (CRP), white blood cell (WBC), and Neutrophil\% (Neu\%)], USG, CT and performing colonoscopy.

Age calculated as mean \pm standard derivation; gender evaluated as male (M) or female (F). LOS calculated as mean \pm standard derivation. The Etiology evaluated as PA, simple PA (SPA), or PA with periappendicular abscess (PAWPA), IBD, suspicion of malignancy, diverticulitis, and other rare etiologies (mucocele, psoas, and tuba ovarian abscess). Treatment evaluated as medical treatment (MT), percutaneous drainage (PD), diagnostic laparoscopy (DL), DL and drainage (DLD), appendectomy (AP), and right hemicolectomy (RH).

CRP $(\mathrm{mg} / \mathrm{L})$, WBC $\left(10^{3} / \mathrm{uL}\right)$, and Neu\% (\%) as mean \pm standard deviation. Colonoscopy evaluated as performed yes or no. USG evaluated as performed but negative or performed and positive. CT evaluated as none, performed but negative or performed and positive.

\section{Statistical Analysis}

The statical analysis performed with SPSS 16.0. Age, LOS, CRP, WBC, Neu\% calculated as mean \pm standard derivation. The ratio of male/female, etiology, treatment, colonoscopy calculated as a percentage. Chi-square, Kruskal-Wallis, and ANOVA were used to evaluate the values, and $\mathrm{p}<0.05$ was accepted as significant.

\section{Results}

One hundred forty four from 177 patients included study. The mean age was $41.35 \pm 17.9$ years for all groups. Male was the most common gender, with a $52.4 \%$ ratio. The mean of LOS was $4.2 \pm 2.6$ days. $28.5 \%$ of the patients performed a colonoscopy. Hypertension and diabetes were the most common comorbidities with $12.5 \%$ and $8.3 \%$ rates, respectively. The most common etiology of PIM was PA with a $75 \%$ rate, and $5.5 \%$ of the patients managed for suspicion of malignancy. $67.3 \%$ of the patients were treated conservatively (medical or percutaneous drainage), and $32.7 \%$ of the patients treated surgically. DL with drainage (25\%) was the most common surgery, and right hemicolectomy performed to $4.9 \%$ of the patients. The pathology of the operated patients except for two right hemicolectomies (gastrointestinal stromal tumor and mucinous cystadenocarcinoma), reported as inflammation. The morbidity reported at seven patients (4.9\%) and includes; recurrence at four patients, pulmonary complication at two patients and, surgical site infection at one patient (Table 1). Suspicion of malignancy was the eldest group with $63.7 \pm 11.8$ years, and other rare etiologies were the youngest group with $36.4 \pm 13.2$ years. Male was the most common gender for all groups; however, the female was the most common gender at PAWPA, IBD, and other rare etiologies. The longest LOS reported at other rare etiologies, and the shortest LOS reported at SPA. Colonoscopy offered and planned six week after from discharge, but most of the patients should not perform colonoscopy. The most common colonoscopy performed group was IBD, subsequently diverticulitis with $76.4 \%$ and $66.6 \%$ rate, respectively. PA was the most common etiology of PIM with $75 \%$, and abscess occurred 
at $32.4 \%$ of the PA. The recurrence rate was $3.7 \%$, and interval AP performed to $1.85 \%$ of the PA. PA was the most common performed MT (SPA) with $78 \%$. PD performed only PAWPA. DL performed to SPA and IBD, and DLD performed to PAWPA and IBD. RH performed to IBD and suspicion of malignancy patients. The highest CRP level measured at other rare etiologies, and the lowest level at diverticulitis. The highest Wbc level measured at PAWPA, and the lowest level measured at other rare etiologies. The highest Neu\% ratio measured at IBD, and the lowest ratio measured at diverticulitis. The differences at age, LOS, treatment, CRP level, Neu\%, and performed colonoscopy between etiology groups were found statistically significant $(\mathrm{p}=0.013, \mathrm{p}=0.004, \mathrm{p}=0.0001, \mathrm{p}=0.005, \mathrm{p}=0.03, \mathrm{p}=0.0001$ respectively) (Table 2 ).

Table 1 . The results of the study (*mean \pm standard deviation)

\begin{tabular}{|c|c|c|}
\hline Age (years) & \multicolumn{2}{|c|}{$41.35 \pm 17.9$} \\
\hline Gender & $\mathrm{n}$ & $\%$ \\
\hline Male & 78 & 54.2 \\
\hline Female & 66 & 45.8 \\
\hline Length of stay (days) & $4.2 \pm$ & \\
\hline Colonoscopy & $\mathrm{n}$ & $\%$ \\
\hline Yes & 41 & 28.5 \\
\hline No & 103 & 71.5 \\
\hline Etiology & $\mathrm{n}$ & $\%$ \\
\hline Plastron appendicitis (PA) & 108 & 75 \\
\hline Simple PA & 73 & 67.6 \\
\hline Periappendicular abcess with PA & 35 & 32.4 \\
\hline IBD & 17 & 11.8 \\
\hline Malignancy? & 8 & 5.5 \\
\hline Diverticulitis & 6 & 4.2 \\
\hline Others & 5 & 3.5 \\
\hline Treatment & $\mathrm{n}$ & $\%$ \\
\hline Medical & 82 & 56.9 \\
\hline Percutaneous drainage & 15 & 10.4 \\
\hline Diagnostic laparoscopy & 12 & 8.3 \\
\hline Diagnostic laparoscopy and drainage & 24 & 16.7 \\
\hline Appendectomy & 4 & 2.8 \\
\hline Right hemicolectomy & 7 & 4.9 \\
\hline Comorbidity & $\mathrm{n}$ & $\%$ \\
\hline Hypertension & 18 & 12.5 \\
\hline Diabetes & 12 & 8.3 \\
\hline Hearth Disease & 7 & 4.9 \\
\hline $\begin{array}{l}\text { Chronic obstructive pulmonary } \\
\text { disease }\end{array}$ & 4 & 2.8 \\
\hline Cerebrovascular accident & 2 & 1.4 \\
\hline Chronic renal failure & 3 & 2.1 \\
\hline Others & 7 & 4.9 \\
\hline
\end{tabular}

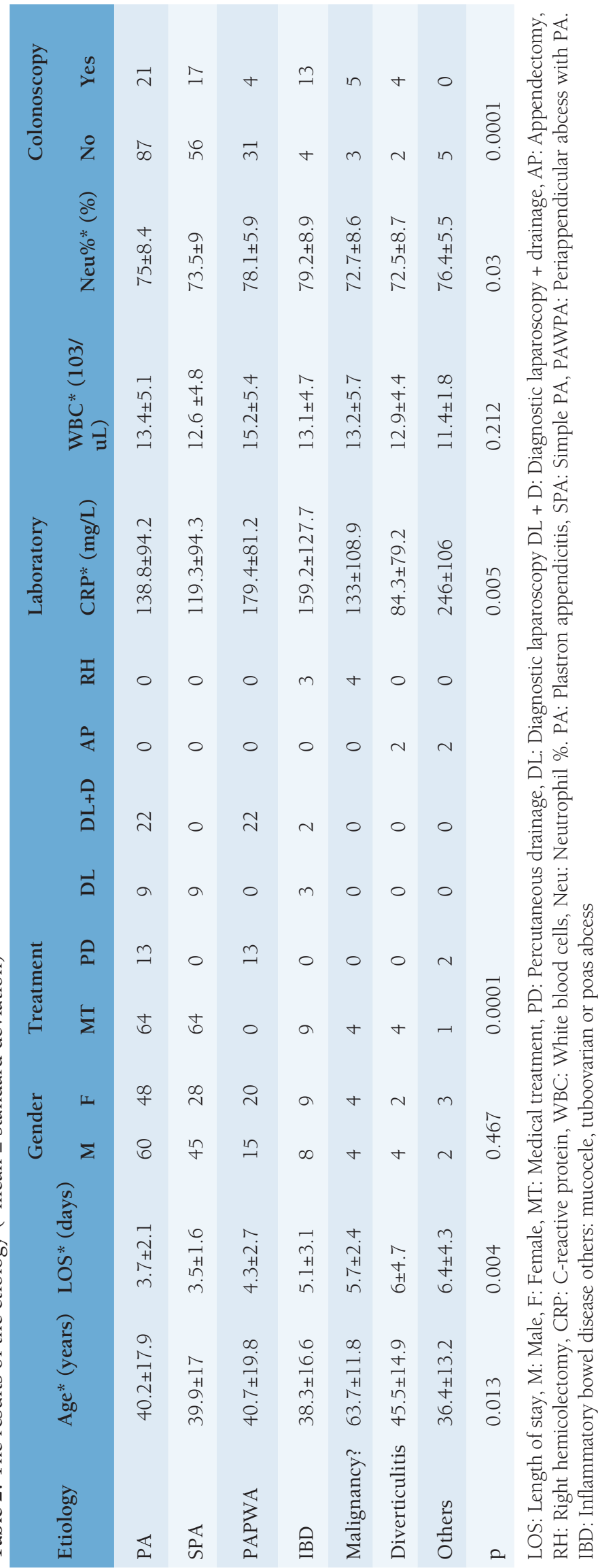


The comparison of USG and CT results due to etiology is given at Table 3. $44.4 \%$ of the all PIM had negative, 55.6\% had positive USG imaging. The most common negative USG imaging found at PAWPA group. $11.1 \%$ of the all PIM had none, $17.4 \%$ had negative, and $71.5 \%$ had positive CT imaging. Except other group the most common positive CT imaging found at diverticulitis group. The CT images of etiologies are given at Figure 1 and 2.

\section{Discussion}

The most common etiology of PIM were PA (SPA or PAWPA), IBD, diverticulitis, mucocele, and malignancy in recent study. Hepatic adenoma, xanthogranulomatous inflammation of terminal ileum, metastasis to an ectopic kidney, tubercular tuba-ovarian cyst, incidental teratoma or appendiceal torsion reported as a inflammatory palapable mass at RLQA in the literature. ${ }^{8,9,10,11,12,13}$

History of abdominal pain, which began 72 hours ago, palpable mass at RLQA, and fever are the most common complaint of PIM. Inflammatory biomarkers like CRP, WBC, Neu\% increases due to the severity of etiology. Plain abdominal radiography can be inadequate for evaluating

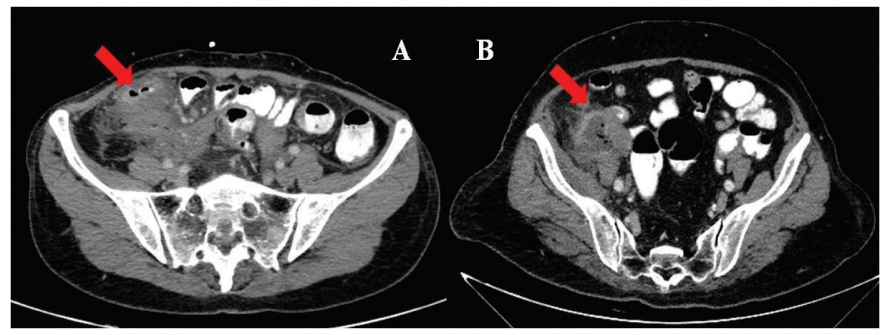

Figure 1. Tomographic images of A: plastron appendicitis, B: plastron appendicitis with periappendicular abscess

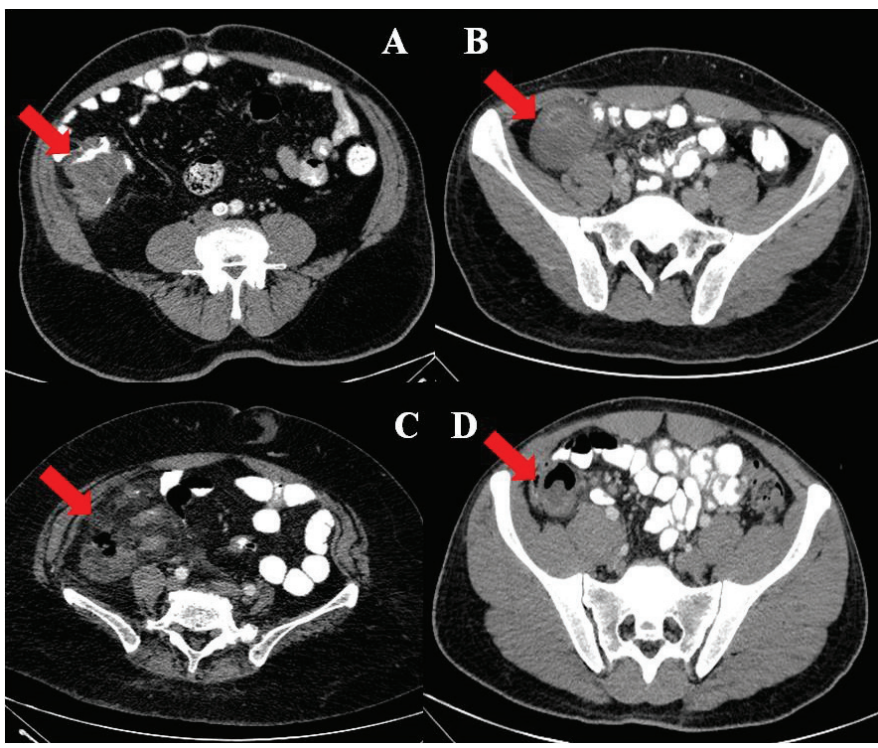

Figure 2. Tomographic images of A: malignancy, B: mucocele, C: diverticulitis, D: inflammatory bowel disease
PIM. USG is the initial imaging modality for the evaluation of PIM. A mass lesion in the RLQA, which cannot clearly distinguish from the appendix, and sometimes accompanied by a dense fluid, can found at USG or Contrast-enhanced CT. Colonoscopy should not prefer at the acute phase of inflammatory disease and prefer after six weeks to clarify the etiology. MR enterography should do for diagnosing the disease of the terminal ileum.

\section{The evaluation of the etiology;}

Plastron appendicitis is a formation of abscess secondary to perforated appendicitis, and follow surrounding by the omentum. The rate of enclosed inflammation is $3.8-5 \%$ of all appendicitis. The incidence of PA in adults reported as $4,8 \%$. The mean age varies from 26 to 53 years, and male is the most common gender for PA in literature. ${ }^{2}$ USG and CT have higher sensitivity, specificity, and accuracy in diagnosing acute appendicitis (86\%, 88\%, 91\%, and 90\%, 93\%, 94\%, respectively). The specificity of CT increased to $95 \%$, while sensitivity decreased to $75 \%$ at complicated appendicitis such as PA or PAWPA. Abscess, extraluminal air, appendiceal wall enhancement, periappendicular fat stranding are useful criteria of complicated appendicitis. ${ }^{14,15,16}$ USG or CT diagnosis is more common than clinical, with a rate of $14.2 \%$ vs $5.1 \%$. The treatment of PA is still controversial. Conservative treatment with antibiotherapy for simple PA, and percutaneous or surgical drainage for PAWPA. There are a $7.2 \%$ recurrence and a $7.6 \%$ failure rate for conservative treatment. Immediate AP is not recommended due to the $35.6 \%$ risk of morbidity, while the risk decreased to $18.4 \%$ at delayed AP, $13.5 \%$ at nonsurgical treatment, and $11 \%$ at additional interval AP with nonsurgical treatment. The success ratio of nonsurgical treatment reported as 93\%, and $20 \%$ of nonsurgical treatment needed drainage. Nonsurgical treatment has a $2 \%$ risk of misdiagnosed. Malignancy detected at following $1.2 \%$ of the nonsurgical treatment and $>40$ years old have an increased risk for malignancy. The recommended follow up at PA after successful conservative treatment consists of colonoscopy, CT, or MRI for especially $>40$ years old patients, and interval AP suggested for recurrent disease and malignancy risk. ${ }^{2,17}$ In the recent study, the mean age was $39.9 \pm 17$ years for SPA, and $40.7 \pm 19.8$ years for PAWPA and male was the most common gender at SPA, however, female was the more common at PAWPA. LOS was shorter at SPA than PWPA $(3.5 \pm 1.6$ vs $4.3 \pm 2.7$ days). SPA was more diagnosed than PAWPA at CT $(72.6 \%$ vs $60 \%$ ); however, the nondiagnosed ratio was similar at CT (20.5\% vs $20 \%$ ). $39.7 \%$ of the SPA and $51.4 \%$ of the PAWPA cannot diagnose at USG. MT or only DL was performed for SPA ( $87.6 \%$ vs $12.4 \%$ ), however DL + drainage or PD was performed for PAWPA (62.9\% vs $37.1 \%$ ). $23.3 \%$ of the SPA and $11.4 \%$ of the PAWPA performed colonoscopy at follow 
Table 3. Comparison of ultrasonography (USG) and computed tomography (CT) results due to etiology

\begin{tabular}{|c|c|c|c|c|c|}
\hline & USG & & BT & & \\
\hline Etiology & $\begin{array}{l}\text { Performed but } \\
\text { negative }\end{array}$ & $\begin{array}{l}\text { Performed and } \\
\text { positive }\end{array}$ & None & $\begin{array}{l}\text { Performed but } \\
\text { negative }\end{array}$ & $\begin{array}{l}\text { Performed and } \\
\text { positive }\end{array}$ \\
\hline SPA & 29 (39.7\%) & $44(60.3 \%)$ & $5(6.8 \%)$ & $15(20.5 \%)$ & $53(72.7 \%)$ \\
\hline PAWPA & $20(57.1 \%)$ & $15(42.9 \%)$ & $6(17.1 \%)$ & 7 (20\%) & $22(62.9 \%)$ \\
\hline IBD & $9(53 \%)$ & $8(47 \%)$ & $3(17.6 \%)$ & $2(11.8 \%)$ & $12(70.6 \%)$ \\
\hline Malignancy? & $4(50 \%)$ & $4(50 \%)$ & $1(12.5 \%)$ & $1(12.5 \%)$ & $6(75 \%)$ \\
\hline Diverticulitis & $2(33 \%)$ & $4(67 \%)$ & $1(17 \%)$ & 0 & $5(83 \%)$ \\
\hline Others & 0 & $5(100 \%)$ & 0 & 0 & $5(100 \%)$ \\
\hline Total & 64 & 80 & 16 & 25 & 103 \\
\hline
\end{tabular}

SPA: Simple PA, PAWPA: Periappendicular abcess with PA, IBD: Inflammatory bowel disease others: mucocele, tuboovarian or psoas abcess

up. The ratio of recurrence reported as $3.7 \%$, performing interval AP reported as $1.86 \%$, and morbidity reported as $2.8 \%$. The pathology of interval appendectomies reported as inflammation. We planned elective colonoscopy and offered interval AP to all PA; however, the compliance rate for recommendation is very poor. $43.5 \%$ of the PA was $>40$ years old, interval AP has not performed anyone, and only $27.7 \%$ performed a colonoscopy.

Inflammatory Bowel Disease (IBD): CD, which located at terminal ileum (terminal ileitis) or ileocolic region, should be occurred inflammatory mass at RLQA. CD reported, $0.85 \%$ of the operated for appendical inflammatory mass and $11.8 \%$ of the CT abnormalities in RLQA. $10-20 \%$ occurred spontaneous abscess, one third occurred palpable mass and 5.3\% misdiagnosed as acute appendicitis at CD. Contrast-enhanced CT is useful for differential diagnosing of CD and complications. Colonoscopy or MR enterography can help clarify the diagnosis of $\mathrm{CD}$. The treatment of $\mathrm{CD}$ includes medical treatment, percutaneous or surgical drainage, or right hemicolectomy due to the severity of the disease. PD preferred at simple and unilocular abscess. Surgical drainage should perform when PD is failure or not suitable, or multilocular. $44 \%$ of the abscess of $C D$ was drained by percutaneously vs. $56 \%$ by surgically. $4,7,17,18,19$ In the recent study, IBD occurred $11.8 \%$ of the PIM. Abscess occurred at $11.8 \%$ of the patients and drained surgically. DL performed to $17.6 \%$ of the CD patients for suspicion of acute appendicitis. Right hemicolectomy to $17.6 \%$ of the patients for the complication of CD. Chronic granulomatous inflammation reported for pathology. The rest of the patients treated medically. Colonoscopy performed to $76.4 \%$ of the patients.

Malignancy of appendix vermiformis and cecum misdiagnosed with complicated appendicitis and RLQ mass can be the initial sign. Malignancy of appendix vermiformis is very rare and constitutes $0.4 \%$ of all gastrointestinal tract. Carcinoid tumor is the most common malignancy; adenocarcinoma represents $10-20 \%$, onethird of adenocarcinoma is mucinous. 6-8.3\% of the right hemicolectomy which performed for inflammatory mass reported as a cecal mesenchymal tumor. Diagnosing of malignancy of appendix and cecum, which presenting with RLQ mass is difficult with clinical or radiological findings, and generally diagnosed at pathology. Colonoscopy can be a useful diagnosing modality for malignancy at selected patients. The surgical treatment constitutes; AP or extends to right hemicolectomy. The conservatively treated patients with malignancy suspicion must follow up closely, and elective colonoscopy planned immediately. ${ }^{6,20,21,22,23}$ In the recent study, malignancy constitutes $5.5 \%$ of the PIM. Suspicion of malignancy with PIM reported at imaging. Right hemicolectomy performed to half of the patients due to the severity of inflammation. Pathology of the appendix was reported active inflammation at two patients, GIST at one patient, and mucinous adenocarcinoma at one patient. Elective colonoscopy performed for the conservative treated patients, and cecal adenocarcinoma reported at two patients pathology and redirected for elective surgery.

Diverticulitis: The left side is the most common side of the colonic diverticulum, and diverticulum at cecum or 
appendix vermiformis is very rare. The incidence of cecal diverticulum was reported as $0.1 \%$, appendical diverticulum was reported as $1.4 \%(0.2-0.66 \%$ from autopsy and $0.004-$ $2.1 \%$ from AP specimens). These diverticulums should be congenital or acquired. The fifth decade is the most common decade for colonic diverticulitis. However, cecal diverticulitis reported as 44.54 years and appendiceal diverticulitis with an average age of 37-39 years. Most of the colonic diverticulum are asymptomatic, but $10-20 \%$ of cecal, and two-thirds of appendiceal diverticulum can complicate with inflammation, perforation, etc. or misdiagnosed as acute appendicitis. The appendiceal diverticulitis has four times higher perforation and mortality rate than acute appendicitis. The clinic or radiologic differential diagnosing of diverticulitis from acute appendicitis is not easy. The diagnosing rate of appendical diverticulitis reported as $0.007 \%$ in the literature. Cecal or appendicular diverticulitis can be treated conservatively if correctly diagnosed and not complicated. Especially appendical diverticulitis operated to presumed as acute appendicitis. ${ }^{6,24,25,26}$ In the recent study, diverticulitis occurred $4.2 \%(n=6)$ of the PIM. Four of the diverticulitis were cecal (66.7\%), and two were appendiceal (33.3\%) diverticulitis. The mean age was 45 years, and the most common male was gender found similar to literature. All cecal diverticulums diagnosed at CT; however, all appendical diverticulums diagnosed at AP specimens. Cecal diverticulitis treated with medical treatment, and colonoscopy performed all patients. Appendical diverticulum treated surgically with AP.

Mucocele is a cystic dilatation of appendix vermiformis, which occurred by blocking with an intraluminal mucus and causing to cystadenocarcinoma from cystic retention (simple mucocele). Mucocele is very rare, occurred $0.25 \%$ of the appendectomies, and constitutes $8 \%$ of appendiceal malignancy. Mucocele should misdiagnose as plastron or complicated appendicitis. A well-encapsulated cystic mass in the RLQA, often associated with mural calcifications found at imaging. AP can be adequate for simple mucocele; however, a right hemicolectomy must perform for mucinous cystadenoma or cystadenocarcinoma. ${ }^{27,28,29}$ In the recent study, $1.85 \%$ of the PIM occurred by the mucocele of the appendix. AP performed, and granulomatous inflammation reported at pathology.

\section{Conclusion}

In conclusion, not only plastron appendicitis but also $\mathrm{CD}$, malignancy, diverticulitis, mucocele, and abscess of neighbor tissues must keep in mind when evaluating the inflammatory mass of right lower quadrant of the abdomen. Age, length of hospital stay, treatment, inflammatory markers, or performing colonoscopy could be significantly different between etiologies. Elective colonoscopy and interval AP at plastron appendicitis are recommending for $>40$ years old patients to exclude malignancy.

\section{Ethics}

Ethics Committee Approval: University of Health Sciences Turkey Okmeydanı Training and Research Hospital Clinical Research Ethics Committee (no: 48670771-514.10)

Informed Consent: Not obtained because the study was retrospective.

Peer-review: Internally and externally peer reviewed.

\section{Authorship Contributions}

Concept: D.Ö.K., M.Y., B.G., S.E., S.H., Design: D.Ö.K., M.Y., B.G., S.E., S.H., Data Collection or Processing: D.Ö.K., M.Y., B.G., S.E., S.H., Analysis or Interpretation: D.Ö.K., M.Y., B.G., S.E., S.H., Literature Search: D.Ö.K., M.Y., B.G., S.E., S.H., Writing: D.Ö.K., M.Y., B.G., S.E., S.H.

Conflict of Interest: No conflict of interest was declared by the authors.

Financial Disclosure: The authors declared that this study received no financial support.

\section{References}

1. Katipoğlu B, Yırgın G, Furkan Demir B, Ateş İ. An unusual cause of chronic diarrhea: plastron appendicitis. Gastroenterol Hepatol Bed Bench 2019;12:74-75.

2. Andersson RE, PetzolMG. Nonsurgical treatment of appendiceal abscess or phlegmon: a systematic review and meta-analysis. Ann Surg 2007;246:741-748.

3. Wright GP, Mater ME, Carroll JT, Choy JS, Chung MH. Is there truly an oncologic indication for interval appendectomy? Am J Surg 2015;209:442446.

4. Deelder JD, Richir MC, Schoorl T, Schuers WH. How to Treat an Appendiceal Inflammatory Mass: Operatively or Nonoperatively? J Gastrointest Surg 2014;18:641-645.

5. Hot S, Eğin S, Gökçek B, Yeşiltaş M, Alemdar A, Akan A, Karahan SR. Solitary caecum diverticulitis mimicking acute appendicitis. Ulus Travma Acil Cerrahi Derg 2015;21:520-523

6. Chandra Mohan S, Gummalla KM, H'ng MWC. Malignant Tumours Mimicking Complicated Appendicitis and Discovered upon Follow-Up after Percutaneous Drainage: A Case of Two Patients. Case Rep Radiol 2017;2017:3253928.

7. Richards RJ. Management of abdominal and pelvic abscess in Crohn's disease. World J Gastrointest Endosc 2011;3:209-212.

8. Mooney MJ, Nyreen MR, Hall RA, Carter PL. Hepatic adenoma presenting as a right lower quadrant mass. Am Surg 1993;59:229-231.

9. Yoon JS, Jeon YC, Kim TY, Han DS, Sohn JH, Nam KW, Nam YS, Pyo JY. Xanthogranulomatous inflammation in terminal ileum presenting as an appendiceal mass: case report and review of the literature. Clin Endosc 2013;46:193-196

10. Lloyd TV, Paul DJ. Metastasis to an ectopic kidney presenting as a right lower quadrant mass. J Urol 1980;123:571-572.

11. Akbulut S, Arikanoglu Z, Basbug M. Tubercular tubo-ovarian cystic mass mimicking acute appendicitis: a case report. J Med Case Rep 2011;10:5:363.

12. Torbati SS, Hogan S, Vos E, Banayan E. Woman with Right Lower Quadrant Mass and Abdominal Pain. J Emerg Med 2014;46:220-222. 
13. Johnson KN, Egan JC. Appendiceal torsion presenting as a right lower quadrant mass. Am Surg 2015;81:E22-4.

14. Bittle MM, Chew FS. Radiological reasoning: recurrent right lower quadrant inflammatory mass. AJR Am J Roentgenol 2005;185(3 Suppl):S188-194.

15. Assefa Z. Management Of Inflammatory Appendiceal Mass In Zewditu Memorial Hospital, Addıs Ababa, Ethıopıa. Ethiop Med J 2016;54:57-62.

16. Bixby SD, Lucey BC, Soto JA, Theysohn JM, Ozonoff A, Varghese JC. Perforated versus nonperforated acute appendicitis: accuracy of multidetector CT detection. Radiology 2006;241:780-786.

17. Tannoury J, Abboud B. Treatment options of inflammatory appendiceal masses in adults. World J Gastroenterol. 2013;19:3942-3950.

18. Gutierrez A, Lee H, Sands BE. Outcome of surgical versus percutaneous drainage of abdominal and pelvic abscesses in Crohn's disease. Am J Gastroenterol 2006;101:2283-2289.

19. Scatarige JC, Yousem DM, Fishman EK, Jones B, Siegelman SS. CT abnormalities in right lower quadrant inflammatory disease: review of findings in 26 adults. Gastrointest Radiol 1987;12:156-162.

20. Kalpande S, Pandya J, Sharma T. Adenocarcinoma mimicking appendicular lump: a diagnostic dilemma-a case report. World J Surg Oncol 2016;14:283.

21. Handler M, Anand N, Wei L, Snieckus P. Adenocarcinoma of the Appendix Presenting as a Palpable Right Thigh Mass. J Radiol Case Rep 2017;11:2029.
22. Poon RT, Chu KW. Inflammatory cecal masses in patients presenting with appendicitis. World J Surg 1999;23:713-716.

23. Guven H, Koc B, Saglam F, Bayram IA, Adas G. Emergency right hemicolectomy for inflammatory cecal masses mimicking acute appendicitis. World J Emerg Surg 2014;9:7.

24. Cristaudo A, Pillay P, Naidu S. Caecal diverticulitis: Presentation and management. Ann Med Surg (Lond) 2015;4:72-75.

25. Friedlich M, Malik N, Lecompte M, Ayroud Y. Diverticulitis of the appendix. Can J Surg 2004;47:146-147.

26. AbdullGaffar, B. Diverticulosis and Diverticulitis of the Appendix. International Journal of Surgical Pathology 2009;17:231-237.

27. Tãrcoveanu E, Vasilescu A, Hee RV, Moldovanu R, Ursulescu C, Ciobanu D, Bradea C. Appendicular Mucocele: Possibilities and Limits of Laparoscopy. Brief Series and Review of the Literature. Chirurgia (Bucur) 2015;110:530-537.

28. Lorenzon L, De Dominicis C, Virgilio E, Balducci G. The appropriate management of an appendiceal mucocele. BMJ Case Rep 2015;2015:bcr2014209045

29. Abuoglu H, Yıldız MK, Kaya B, Odabaşı M. Clinicopathological analysis of patients operated for appendiceal mucocele. Ulus Travma Acil Cerrahi Derg 2017;23:230-234. 